\title{
Cost of Illness of Japanese Patients with Chronic Lymphocytic Leukemia (CLL), and Budget Impact of the Market Introduction of Ibrutinib
}

\author{
Jörg Mahlich ${ }^{1,2} \cdot$ Shinichiro Okamoto ${ }^{3} \cdot$ Akiko Tsubota $^{2}$
}

Published online: 27 April 2017

(c) The Author(s) 2017. This article is an open access publication

\begin{abstract}
Background Ibrutinib was introduced in Japan in 2016 as a new oral treatment option for patients with relapsed/refractory (RR) chronic lymphocytic leukemia (CLL). There is increasing interest from the Japanese government to assess economic aspects of new medical interventions, especially in the area of oncology.

Objective We describe the treatment patterns of Japanese patients with CLL, estimate the cost of the disease from a health insurance perspective, and predict the budget impact of the introduction of ibrutinib.

Methods A budget impact model was set up and populated with data that were collected from a survey of Japanese hematologists $(n=202)$ and official statistics. Uncertainty was addressed by one-way sensitivity analysis of several model parameters.

Results Among the 2000 Japanese CLL patients, 42.2\% have not yet commenced medical treatment, $29.1 \%$ were on a treatment break, and $26.8 \%$ received medical treatment, mainly rituximab in combination with either fludarabine or bendamustine. Among the patients under medical treatment, $65.7 \%$ were receiving first-line treatment and $34.3 \%$ were
\end{abstract}

Electronic supplementary material The online version of this article (doi:10.1007/s41669-017-0024-5) contains supplementary material, which is available to authorized users.

Shinichiro Okamoto

okamoto@a7.keio.jp

1 Düsseldorf Institute for Competition Economics (DICE), University of Düsseldorf, Düsseldorf, Germany

2 Department of Health Economics, Janssen Pharmaceutical K.K., Tokyo, Japan

3 Division of Hematology, Department of Medicine, Keio University School of Medicine, Tokyo, Japan receiving second-line or later treatment. In Japan, the estimated burden of illness for 2015 was $¥ 1563$ million for RR CLL and $¥ 5471$ million for overall CLL. The expected average budget impact of introducing ibrutinib is $¥ 3077$ million per year for the next 5 years.

Conclusion Due to low disease prevalence, the burden of illness in Japan is low compared with Western countries.

\section{Key Points for Decision Makers}

Due to a low prevalence of CLL in Japan, the burden of illness is low compared with Western countries.

The expected average budget impact of introducing ibrutinib is $¥ 3077$ million per year for the next 5 years.

Ibrutinib is a treat-to-progression drug, therefore duration of treatment may vary based on the status of individual patients.

\section{Introduction}

Chronic lymphocytic leukemia (CLL) is the most common type of adult leukemia in Western countries; however, in Asia and Japan this disease is very rare, with the incidence in Japan being reported to be far below $0.5 / 100,000$ personyears [1-3]. Although the incidence is quite low, it is increasing in Asia, including in Japan [4]. From this observation, some authors infer that environmental factors such as a westernization of lifestyle may be related to this rise [5], while others suggest that there is a genetic basis for 
the geographic variations in incidence, and development of CLL requires the interaction of a genetic predisposition with exposure to various environmental factors $[3,6]$. In Asian populations, males seem to be affected more often than females [7]. Because of the small number of mostly elderly patients, there is only limited information on how Japanese patients are treated in clinical practice. Moreover, CLL in Japan is characterized by a high degree of heterogeneity with regard to morphology and immune phenotypes, making it difficult to diagnose [8].

With the market introduction of ibrutinib in May 2016, a new oral treatment option became available for Japanese patients with relapsed/refractory (RR) CLL, i.e. patients who did not respond to, or relapsed after, their first-line treatment. Patients treated with the orally available Bruton tyrosine kinase (BTK) inhibitor ibrutinib experienced a partial reconstitution of normal $\mathrm{B}$ cells and humoral immunity [9]. Compared with ofatumumab as the current standard of care in this indication, treatment with ibrutinib demonstrated a statistically significant improvement, both in progression-free survival (PFS) [hazard ratio (HR) 0.22, $p<0.001]$ and overall survival (OS) [HR 0.43, $p=0.005$ ) [10]. However, there remains some uncertainty in the magnitude of clinical benefit with ibrutinib as the median PFS and OS have not been reached. With regard to patientreported outcomes, a clinically meaningful improvement in both fatigue measures and global health scores was reported in the ibrutinib arm [10].

This improvement in both duration and quality of life comes at a cost. Due to the longer treatment duration of ibrutinib, which requires treatment to progression, compared with ofatumumab, which is a fixed duration treatment, drug acquisition costs are higher. However, directly associated medical costs of ibrutinib are lower due to cost offsets with regard to administration and toxicity. We estimate the budget impact from the perspective of the Japanese National Health Insurance from June 2016 June to May 2020. This study fills a void in that it describes treatment patterns in Japan and estimates the costs of treating Japanese patients with RR CLL.

\section{Methods}

We employed a budget impact model that covers a 5-year period. It is built from a health insurance perspective in that it only includes direct medical costs and does not account for quality-of-life improvements or increased survival related to specific treatments. Only costs associated with CLL treatment are considered and the model does not attempt to quantify the clinical benefits. Major drivers of the budget impact are (1) the number of treated patients and duration of treatment; (2) drug prices and respective market shares; and (3) toxicity and administration costs. All costs are reported in Japanese Yen; as of May 2016, $¥ 100$ were traded at US\$0.9. Future costs should be discounted using the long-term interest rate for government bonds; however, in the case of Japan, there was no need to discount future costs as the 5-year interest rate in Japan is close to $0 \%$, according to the Japanese Ministry of Finance [11]. Results were checked for robustness by employing a one-way sensitivity analysis.

\subsection{Number of Patients and Treatment Path}

The number of Japanese patients with CLL is taken from official statistics published by the Ministry of Health, Labor and Welfare (MHLW). According to these estimates, the total number of patients with CLL is 2000 [12], which corresponds to a $0.00157 \%$ prevalence within the total Japanese population of $127,298,000$ [13]. Note that the number of CLL patients also includes patients who have small lymphocytic lymphoma (SLL). The differences between CLL and SLL are only minor and relate to differences in clinical presentation. A CLL type would be characterized by peripheral blood B cell lymphocytosis, as well as lymphadenopathy, organomegaly, cytopenias, and systemic symptoms, whereas the lack of peripheral blood lymphocytosis would be classified as a form of SLL [14].

To estimate the patient allocation to different treatment lines, a nationwide survey among 202 Japanese hematologists was conducted (Online Appendix 1). The survey was carried out in August 2014 and collected information relating to the number of patients as well as medical treatment, including treatment durations in different treatment lines. The survey was carried out by the Social Survey Research Information Co., which non-randomly contacted, by e-mail, 3182 hematologists who worked in large hospitals of over 100 beds. Despite a response rate of just $6.3 \%$, the physicians who filled out the questionnaire treated 858 patients in total, representing $43 \%$ of the total Japanese CLL patient population.

The results were extrapolated to the total patient population and indicate that 352 patients were receiving firstline treatment, while 184 patients received second- or third-line treatment, i.e. the ibrutinib indication and the subject of this analysis (Table 1). The remaining patients were in a period of 'watch and wait', meaning they have not yet commenced medical treatment or they were between different treatment lines.

\subsection{Treatment Regimens, Costs, and Market Share}

Table 2 shows treatment regimens and costs; reimbursement list prices for each existing treatment drug are from the National Health Insurance [15, 16]. It is important to 
Table 1 Allocation of Japanese CLL patients across treatment lines

\begin{tabular}{llll}
\hline Treatment line & $\begin{array}{l}\text { Patient allocation to } \\
\text { treatment } \\
\text { line }(\%)\end{array}$ & $\begin{array}{l}\text { Length in month (standard } \\
\text { deviation) } \\
\text { in each treatment line }\end{array}$ & $\begin{array}{l}\text { Number of patients in each stage } \\
\text { (under the assumption of } \\
\text { prevalence of 2000) }\end{array}$ \\
\hline $\begin{array}{l}\text { Watch and wait } \\
\text { (WW) }\end{array}$ & 42.6 & $22.56(39.71)$ & 852 \\
$\begin{array}{l}\text { 1st line } \\
\text { WW after 1st }\end{array}$ & 17.6 & $7.7(13.01)$ & 352 \\
line & 20.1 & $16.44(19.27)$ & 402 \\
$\begin{array}{l}\text { 2nd line } \\
\text { WW after 2nd }\end{array}$ & 7.1 & $5.14(6.17)$ & 130 \\
line & $18.56(27.37)$ & 142 \\
3rd line & 2.7 & $2.94(1.99)$ & 54 \\
WW after 3rd & 1.9 & $5.22(6.39)$ & 38 \\
line & & NA & 28 \\
Not specified & 1.4 & & \\
\hline
\end{tabular}

Patient population sums up to 1998 due to rounding errors

$W W$ watch and wait, $C L L$ chronic lymphocytic leukemia

Table 2 Treatment regimens and drug acquisition costs

\begin{tabular}{|c|c|c|c|c|c|}
\hline $\begin{array}{l}\text { Treatment regimens which } \\
\text { is limited treatment period }\end{array}$ & $\begin{array}{l}\text { Reimbursement } \\
\text { price per mg }\end{array}$ & \multicolumn{2}{|l|}{ Dosage regimen } & Source & $\begin{array}{l}\text { Cost per } \\
\text { treatment }\end{array}$ \\
\hline \multicolumn{6}{|c|}{ Bendamustine, rituximab (BR) } \\
\hline Bendamustine & $¥ 949.95$ & \multirow{2}{*}{\multicolumn{2}{|c|}{$\begin{array}{l}1 \text { st cycle }(635.63 \mathrm{mg} \text { rituximab at day } 0+152.55 \mathrm{mg} \text { bendamustine at } \\
\text { day } 1 \text { and } 2) 2 \mathrm{nd} \text { to } 6 \text { th cycle }(847.5 \mathrm{mg} \text { rituximab at day } \\
1+152.55 \mathrm{mg} \text { bendamustine at day } 1 \text { and } 2)\end{array}$}} & {$[18,19]$} & $¥ 3,830,767$ \\
\hline Rituximab & $¥ 427.63$ & & & & \\
\hline \multicolumn{6}{|c|}{ Fludarabine, cyclophosphamide, rituximab (FCR) } \\
\hline Fludarabine & $¥ 685.04$ & \multirow{3}{*}{\multicolumn{2}{|c|}{$\begin{array}{l}\text { 1st cycle }(42.4 \mathrm{mg} \text { fludarabine }+423.75 \\
\text { cyclophosphamide }+635.63 \mathrm{mg} \text { rituximab at day } 1+42,4 \mathrm{mg} \\
\text { fludarabine }+423.75 \text { cyclophosphamide at day } 2 \text { and } 3) 2 \mathrm{nd} \text { cycle to } \\
\text { 6th cycle }(42,4 \mathrm{mg} \text { fludarabine }+423.75 \\
\text { cyclophosphamide }+847.50 \mathrm{mg} \text { rituximab at day } 1+42,4 \mathrm{mg} \\
\text { fludarabine }+423.75 \text { cyclophosphamide at day } 2 \text { and } 3)\end{array}$}} & {$[20]$} & $¥ 2,626,657$ \\
\hline Cyclophosphamide & $¥ 2.51$ & & & & \\
\hline Rituximab & $¥ 427.63$ & & & & \\
\hline Ofatumumab & $¥ 275.15$ & \multicolumn{2}{|c|}{$\begin{array}{l}2000 \mathrm{mg} \text { per week (first week } 300 \mathrm{mg} \text { ) from } 1 \text { st to } 8 \text { th week. } 2000 \mathrm{mg} \\
\text { every four weeks from } 9 \text { th to } 24 \text { th week }\end{array}$} & {$[10]$} & $¥ 6,135,734$ \\
\hline \multicolumn{2}{|c|}{ Treatment regimen which is long term use type } & Reimbursement price per tablet & Dosage regimen & Source & Annual cost \\
\hline \multicolumn{2}{|l|}{ Ibrutinib } & $¥ 9367$ & 3 tablets per day & {$[10]$} & $¥ 10,256,865$ \\
\hline
\end{tabular}

note the differences in duration of treatment between ibrutinib and the current standard of care. While current treatment regimens are administered using a fixed number of treatment cycles, ibrutinib is administered continuously until disease progression [17].

The standard of care costs are calculated based on the duration of each treatment line (Table 1). For ibrutinib, the durations of treatment are based on the extrapolated PFS, based on a fitted PFS curve (Online Appendix 2). The simulation is necessary because, after a 16-month observation period, the median PFS was not reached in the clinical trial. Based on the simulation, the median PFS was estimated to be 31 months [10]. Table 2 does not include alemtuzumab, which was not on the market at the time we conducted our survey.

The current and predicted future market shares of the respective drugs are necessary in order to complete the estimated budget impact of ibrutinib. The calculation of existing and future market shares is based on the same survey that was mentioned above and results are reported in Table 3. The market shares refer to new patients.

\subsection{Toxicity and Administration Costs}

Direct medical costs, such as costs associated with treatment administration and treating toxicities caused by the anticancer 
Table 3 Future market shares

\begin{tabular}{llll}
\hline & Pre ibrutinib (2015), \% & Post ibrutinib (2016), \% & Post ibrutinib (2017-2020), \% \\
\hline 2nd line market share (\%) & & & 70 \\
Current (2015) treatment regimen & 100 & 85 & 22.58 \\
$\quad$ Bendamustine, rituximab & 32.3 & 27.41 & 33.87 \\
$\quad$ Fludarabine, cyclophosphamide, rituximab & 48.38 & 41.12 & 13.54 \\
$\quad$ Ofatumumab & 19.40 & 16.49 & 30 \\
Ibrutinib & 0 & 15 & 40 \\
3rd line market share (\%) & 100 & 70 & 60 \\
Current (2015) treatment regimen & 0 & 30 & \\
Ibrutinib & & & \\
\hline
\end{tabular}

Source: Social Survey Research Information, Ltd

Table 4 Toxicity treatment

\begin{tabular}{|c|c|c|c|c|c|}
\hline Toxicity & Treatment type & Unit costs & Units & Source & $\begin{array}{l}\text { Total } \\
\text { Costs }\end{array}$ \\
\hline \multirow[t]{3}{*}{ Anaemia } & Blood transfusion & $\begin{array}{l}¥ 4500 \text { (first } \\
\text { transfusion) }\end{array}$ & 2 & {$[15]$} & $¥ 24,805$ \\
\hline & & $\begin{array}{l}¥ 3500 \text { (second } \\
\text { transfusion) }\end{array}$ & & & \\
\hline & Irradiation red blood cell: LR $(400 \mathrm{ml})$ & $¥ 16,805$ & 1 & {$[16]$} & \\
\hline $\begin{array}{l}\text { Febrile neutropenia/leukopenia/ } \\
\text { infection }\end{array}$ & $\begin{array}{l}\text { Red cross polyglobin N5\% intravenous injection type } \\
2.5 \mathrm{~g} / 100 \mathrm{~mL}\end{array}$ & $¥ 40,438$ & 3 & {$[16,23]$} & $¥ 121,314$ \\
\hline \multirow[t]{3}{*}{ Thrombocytopenia } & Blood transfusion & $\begin{array}{l}¥ 4500 \text { (first } \\
\text { transfusion) }\end{array}$ & 2 & {$[15]$} & $¥ 166,938$ \\
\hline & & $\begin{array}{l}¥ 3500 \text { (second } \\
\text { transfusion) }\end{array}$ & & & \\
\hline & Irradiation platelet concentrate: $\mathrm{LR}(250 \mathrm{~mL})$ & $¥ 158,938$ & 1 & {$[16]$} & \\
\hline
\end{tabular}

therapies, need to be accounted for in a budget impact model. Administration costs for the bendamustine-rituximab (BR) and fludarabine-cyclophosphamide-rituximab (FCR) regimens are included in the lump sum reimbursement fees as both treatment regimens have their appropriate diagnosis procedure combination (DPC) code. The DPC system is a quasi diagnosis related groups (DRG)-type daily flat fee system that was introduced in 2003 for large hospitals in Japan, and covers more than $90 \%$ of acute inpatient care [21]. The DPC code for BR is 130030xx99xx50x and is associated with 10,239 points, which are worth $¥ 10$ per point [22]. Daily reimbursement, including drug costs, is therefore $¥ 102,390$. Treatment requires 7 days in hospital per cycle, therefore reimbursement for a treatment of six cycles would be $¥ 4,300,380$. Subtracting the drug costs of $¥ 3,830,767$ million from the total reimbursed costs (Table 2) results in a total administration cost of $¥ 469,613$. Furthermore, the daily reimbursement rate for the FCR regimen is $¥ 62,310$ (DPC code 130030xx99xx40x) [22]. Six cycles with 8 days in hospital per cycle gives $¥ 2,990,880$, therefore subtracting the drug costs leads to administration costs of $¥ 364,223$.
On the other hand, ofatumumab and ibrutinib do not have their own DPC code. The administration cost for ofatumumab is calculated by taking the daily basic reimbursement fee of $¥ 15,990$ for specialized hospitals, and assuming 2 days in hospital per cycle. Furthermore, 24 cycles are assumed [10], leading to total administration costs of $¥ 767,520$. The assumption of 2 days of hospitalization per cycle is based on the expert opinion of Professor Okamoto, Hematologist at Keio University Hospital and one of the authors of this study. Ibrutinib is administered in an outpatient setting and administration costs are calculated by adding the basic outpatient care (73 points) and prescription fee (68 points), resulting in $¥ 1410$ per visit [15]. Ibrutinib is administered in a 2-weekly interval, thus administration costs total $¥ 36,761$ per year.

For the treatment of toxicities, we assume the treatment that is reported in Table 4, based on the expert opinion of Professor Okamoto. To find the average costs per patient, one has to multiply the treatment costs of Table 4 with the probability that a certain side effect occurs. Those probabilities are reported in Table 5 and are based on clinical 
Table 5 Treatment specific risks and costs

\begin{tabular}{|c|c|c|c|c|c|c|c|}
\hline Annual risk of grade $3 / 4$ toxicities by regimen & Source & $\begin{array}{l}\text { Anemia } \\
(\%)\end{array}$ & $\begin{array}{l}\text { Febrile } \\
\text { neutropenia } \\
(\%)\end{array}$ & $\begin{array}{l}\text { Leukopenia } \\
(\%)\end{array}$ & $\begin{array}{l}\text { Thrombocytopenia } \\
(\%)\end{array}$ & $\begin{array}{l}\text { Infection } \\
(\%)\end{array}$ & Costs \\
\hline Bendamustine + rituximab & {$[24]$} & 5.8402 & 0.0000 & 5.1316 & 9.3947 & 2.6842 & $¥ 26,614$ \\
\hline Fludarabine + cyclophosphamide + rituximab & {$[25]$} & 6.8571 & 6.8571 & 0.0000 & 6.2857 & 2.8671 & $¥ 23,978$ \\
\hline Ofatumumab & {$[10]$} & 10.8148 & 3.8518 & 0.0000 & 6.2222 & 10.0741 & $¥ 29,964$ \\
\hline Ibrutinib & {$[10]$} & 2.1677 & 1.5871 & 1.0065 & 2.1677 & 7.7419 & $¥ 16,695$ \\
\hline
\end{tabular}

Table 6 Variations for one-way sensitivity analysis

\begin{tabular}{|c|c|c|c|c|c|}
\hline Parameters & $\begin{array}{l}\text { Base } \\
\text { case }\end{array}$ & Distribution & Min & Max & Source \\
\hline Length of WW after 2nd line in months & 18.56 & $t$-Distribution & 8.69 & 28.43 & $\begin{array}{l}\text { A nationwide survey among } 202 \text { Japanese } \\
\text { hematologists }\end{array}$ \\
\hline $\begin{array}{l}\text { Length of treatment period of ibrutinib in } \\
\text { months }\end{array}$ & 31.00 & Normal distribution & 26.65 & 35.35 & Byrd et al. [13] \\
\hline Length of 3rd line treatment in months & 2.94 & $t$-Distribution & 1.96 & 3.93 & $\begin{array}{l}\text { A nationwide survey among } 202 \text { Japanese } \\
\text { hematologists }\end{array}$ \\
\hline Length of 2 nd line treatment in months & 5.15 & $t$-Distribution & 3.79 & 6.50 & $\begin{array}{l}\text { A nationwide survey among } 202 \text { Japanese } \\
\text { hematologists }\end{array}$ \\
\hline Length of hospital stay for FCR treatment & 8.00 & $\begin{array}{l}=/-20 \% \text { of mean } \\
\text { value }\end{array}$ & 6.40 & 9.60 & Expert opinion \\
\hline Number of CLL patients & 2000 & $\begin{array}{l}=/-20 \% \text { of mean } \\
\quad \text { value }\end{array}$ & 1600 & 2400 & Ministry of Health, Labor and Welfare [12]. \\
\hline
\end{tabular}

$W W$ watch and wait, FCR fludarabine, cyclophosphamide, rituximab

trials. Due to differences in the durations of clinical trials, we annualize the respective risk rates for the different regimens.

\subsection{Sensitivity Analysis}

Table 6 reports the parameters that were included, namely second-line treatment duration, duration of 'watch and wait' after second-line treatment, third-line treatment duration, treatment duration of ibrutinib, duration of hospital stay for FCR treatment, and number of CLL patients. The minimum and maximum values in the sensitivity analysis are defined by the $95 \%$ confidence interval. We assumed either a normal or $t$-distribution. As the duration of hospital stay is based on the opinion of a single expert, no distribution is available and we set the minimum and maximum as $20 \%$ below and above the mean. The same applies for the number of CLL patients.

\section{Results}

According to our budget impact model, the current treatment costs for RR CLL were $¥ 1563$ million (US\$14 million) in 2015 (Table 7). The market introduction of ibrutinib in 2016 was estimated to increase the yearly average expenditure for the treatment of patients with RR CLL to $¥ 4639$ million (US $\$ 42$ million) within 5 years. One reason behind the cost increase is the additional number of treated patient-years due to better longevity and longer treatment duration with ibrutinib. With ibrutinib, an additional 200 patient-years will be added compared with the current standard of care. Total costs per patient per year are expected to increase from $¥ 2.96$ million in 2016 to $¥ 7.88$ million in 2020 .

The results of the sensitivity analysis are reported in Fig. 1. The $x$-axis denotes the difference between the 5 -year costs with and without ibrutinib. The greatest impact on the results is the number of CLL patients. In addition, variation in the duration of the 'watch and wait' period after second-line treatment of the current treatment regimen has a big impact on treatment costs. This is because, in the current treatment scheme, second-line treatment is administered only up to 24 weeks (ofatumumab), or up to six cycles (BR, FCR). After that, a 'watch and wait' period follows until the disease progresses and third-line treatment is initiated. On the other hand, with ibrutinib there is no 'watch and wait' period and patients receive treatment until disease progression. The longer the 'watch and wait' period of the current treatment scheme is, the higher the cost 
Table 7 Burden of disease of RR CLL and five-year budget impact with and without Ibrutinib (million Japanese Yen)

\begin{tabular}{lllllll}
\hline & $\begin{array}{l}\text { Cost of } \\
\text { illness RR } \\
\text { CLL (2015) }\end{array}$ & $\begin{array}{l}\text { Cost of illness RR } \\
\text { CLL per patient per } \\
\text { year }\end{array}$ & $\begin{array}{l}\text { Total Cost RR CLL } \\
\text { w/o ibrutinib } \\
(2016-2020)\end{array}$ & $\begin{array}{l}\text { Total Costs RR CLL } \\
\text { with ibrutinib } \\
(2016-2020)\end{array}$ & $\begin{array}{l}\text { RR CLL with } \\
\text { ibrutinib } \\
(2020)\end{array}$ & $\begin{array}{l}\text { RR CLL with ibrutinib } \\
\text { per patient per year } \\
(2020)\end{array}$ \\
\hline $\begin{array}{l}\text { Anticancer } \\
\text { drug }\end{array}$ & 1370.52 & 2.60 & 6852.60 & $22,474.40$ & 5932.26 \\
$\begin{array}{l}\text { acquisition } \\
\text { costs }\end{array}$ & & & & & 7.70 \\
$\begin{array}{l}\text { Administration } \\
\text { costs }\end{array}$ & 174.62 & 0.33 & 867.12 & 639.85 & 119.26 \\
$\begin{array}{l}\text { Toxicity related } \\
\text { costs }\end{array}$ & 18.59 & 0.04 & 92.97 & 83.62 & 0.15 \\
$\begin{array}{l}\text { Total (5 years) } \\
\text { Total annual } \\
\text { average }\end{array}$ & 1562.74 & 2.96 & 7813.69 & $23,197.89$ & 0.02 \\
\hline
\end{tabular}

$C L L$ chronic lymphocytic leukemia, $R R C L L$ relapsed/refractory chronic lymphocytic leukemia

difference is to ibrutinib. For example, if the 'watch and wait' period is only 8.7 months instead of 18.6 months, the 5-year budget impact of ibrutinib would be ¥14,525 million instead of $¥ 15,396$ million. For the same reason, the duration of ibrutinib treatment also has a positive impact on the budget. Furthermore, the duration of hospitalization would only have a very marginal impact on the total treatment costs.

\section{Discussion}

How does the budget impact of reimbursing ibrutinib in Japan compare with the cost of ibrutinib in other countries? Other studies report the cost of illness for CLL and not, as we do here, the cost of RR CLL. According to our survey, some $40 \%$ of Japanese CLL patients are beyond their firstline treatment and belong to the RR subpopulation. The current total burden of CLL in general would therefore add up to approximately $¥ 5471$ million (US\$43.8 million) per year. This value compares to $€ 201$ million (US\$217 million) in Germany due to a much higher prevalence of CLL (almost $0.005 \%$ in Germany vs. 0.0016\% in Japan) [26]. The German study also calculated the societal costs of CLL by including productivity losses that were caused by sick leave. With these types of indirect costs, the cost of illness would increase by $60 \%$ to $€ 321$ million (US\$357 million). This result shows that productivity costs are massive, even for an older patient population. The inclusion of productivity costs in our model would probably lower the budget impact of ibrutinib because treatment with ibrutinib would allow patients who are still of working age to stay in employment for a longer period of time, giving rise to cost offsets from a societal point of view. Those cost offsets could occur even though the average age of CLL patients is above 65 years. This is because the factual retirement age in Japan is very high in international comparison and 8 million of 64 million people in the Japanese labor force are above the age of 65 years [27].

Compared with Germany, where an average lymphoma patient spends 27 days per year in hospital [28], the durations of hospitalization seem to be up to twice as high in Japan. This reflects the general observation of long durations of stay in Japanese hospitals, which is attributed to cultural norms and institutional differences [29]. The German paper used slightly different categories, namely inpatient cost, outpatient costs, drug costs, and nursing costs. On a patient-year basis, Germany reported annual direct medical costs of $€ 4365$ attributable to CLL, i.e. approximately $¥ 533,000$ (based on exchange rates as of May 2016). Drug acquisition costs were $€ 1963$ ( $¥ 239,000$ ). These numbers compare with costs per patient-year of $¥ 2.96$ million in Japan. Of this amount, ¥2.6 million are drug acquisition costs. It is important to note that the German study reports results for the years 2007/2008 and, at that time, modern treatments such as bendamustine or ofatumumab were not yet available. In addition, our study reports costs for RR patients, while the German study reports on averages across all treatment lines. For these reasons, per-patient values are difficult to compare.

Compared with the US, the total estimated Japanese treatment costs of US\$43.8 million for the treatment of CLL are much smaller. A recent study found that, in the US, the annual drug costs for treating CLL were US\$731 million, even before the introduction of ibrutinib [30]. This big variation in treatment costs between the different countries can have multiple reasons, besides the differences in prevalence. Some study results suggest that CLL is clinically more aggressive in Asian populations compared with Western populations $[31,32]$, which might 
Fig. 1 One-way sensitivity analysis, Tornado chart
Number of CLL patients

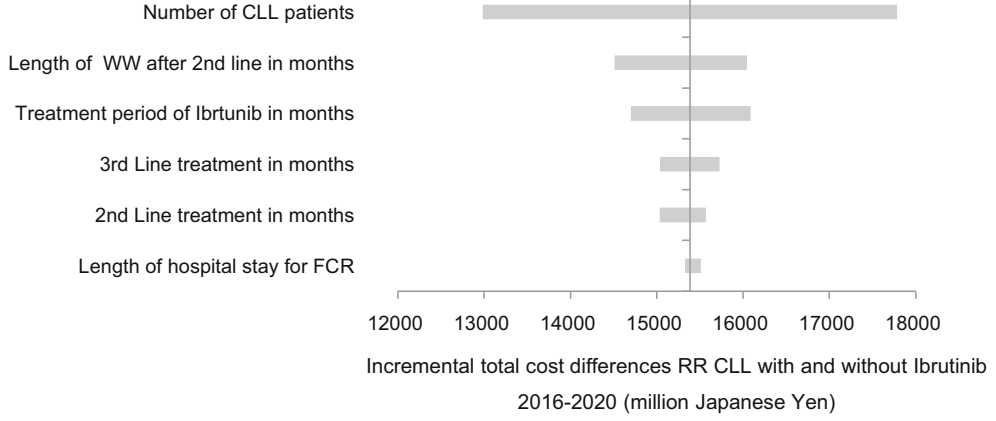

result in the utilization of more aggressive and expensive treatment options as well as in shorter periods of "watch and wait'. Differences in healthcare systems are also important. For instance, the US system leaves the healthcare market largely unregulated in terms of price setting and does, on average, have higher prices for both health services and drugs [33, 34]. For this reason, Germany is probably a more appropriate benchmark for Japan than the US.

It is important to note that this model only reports costs that accrue for health insurance, and does not make any statement on potential benefits of the treatment with ibrutinib, such as a reduction in mortality and morbidity (i.e. quality of life changes), which would be the subject of a cost-effectiveness analysis. We also acknowledge the high degree of uncertainty that is associated with a long run projection of costs. This uncertainty can go in two directions. On the one hand, new treatment options might become available that are even more effective and more expensive. In addition, the ibrutinib treatment duration might be longer than assumed in this model if PFS turns out to be much better than extrapolated. On the other hand, we might find out that a shorter duration of treatment, with ibrutinib, is as effective as a longer treatment. This was at least the lesson from the STIM trial in chronic myeloid leukemia (CML). The results of this trial suggest that imatinib can be safely discontinued in patients with a complete molecular response (CMR) of at least 2 years' duration without any negative effect on the probability on relapse [35].

As a potential limitation, we acknowledge a possible response bias in the survey towards physicians in big hospitals treating many patients. The observed treatment patterns are not necessarily representative for physicians in smaller institutions who only have a few patients. In addition, the estimates of drug administration costs for ofatumumab and ibrutinib are vague because costings for these drugs are based on daily reimbursement fees rather than specific DPC codes.

Despite this uncertainty, we believe that our study relating to the budget effects of a new medical intervention is a valuable tool for policy makers and clinicians. In fact, a very simplified form of a budget impact estimate has already been implemented in the Japanese drug pricing process. In the future, health economic analysis will become even more important in Japan; therefore, both policy makers and decision makers in clinical practice should develop a better understanding of health economic concepts to ensure optimal resource allocation of scarce resources in a super ageing society such as Japan.

Data Availability Statement The datasets generated and/or analyzed during the current study are available from the corresponding author on reasonable request.

Author contributions JM drafted the manuscript and designed the study; SO interpreted the results, critically revised the article, and provided expert opinion on CLL treatment in Japanese hospitals; AT collected the data and was involved in the study design and population of the model. All authors gave approval for the final version to be published.

\section{Compliance with Ethical Standards}

Conflict of interest Jörg Mahlich and AkikoTsubota are employees of Janssen Pharmaceutical K.K. Shinichiro Okamoto has received honoraria from Janssen Pharmaceutical K.K.

Funding This study was funded by Janssen Pharmaceutical K.K.

Open Access This article is distributed under the terms of the Creative Commons Attribution-NonCommercial 4.0 International License (http://creativecommons.org/licenses/by-nc/4.0/), which permits any noncommercial use, distribution, and reproduction in any medium, provided you give appropriate credit to the original author(s) and the source, provide a link to the Creative Commons license, and indicate if changes were made.

\section{References}

1. Tamura K, Sawada H, Izumi Y, Fukuda T, Utsunomiya A, Ikeda $\mathrm{S}$, et al. Chronic lymphocytic leukemia (CLL) is rare, but the proportion of T-CLL is high in Japan. Eur $\mathrm{J}$ Haematol. 2001;67:152-7. 
2. Aoki R, Karube K, Sugita Y, Nomura Y, Shimizu K, Kimura Y, et al. Distribution of malignant lymphoma in Japan: analysis of 2260 cases, 2001-2006. Pathol Int. 2008;58:174-82.

3. Dores GM, Anderson WF, Curtis RE, Landgren O, Ostroumova E, Bluhm EC, et al. Chronic lymphocytic leukemia and small lymphocytic lymphoma: overview of the descriptive epidemiology. Br J Haematol. 2007;139:809-19.

4. Wu SJ, Huang SY, Lin CT, Lin YJ, Chang CJ, Tien HF, et al. The incidence of chronic lymphocytic leukemia in Taiwan, 1986-2005: a distinct increasing trend with birth-cohort effect. Blood. 2010;116:4430-5.

5. Chihara D, Ito H, Matsuda T, Shibata A, Katsumi A, Nakamura $\mathrm{S}$, et al. Differences in incidence and trends of haematological malignancies in Japan and the United States. Br J Haematol. 2014;164(4):536-45.

6. Ruchlemer R, Polliack A. Geography, ethnicity and "roots" in chronic lymphocytic leukemia. Leuk Lymphoma. 2013;54(6):1142-50.

7. Lim RB, Loy EY, Lim GH, Zheng H, Chow KY, Lim ST, et al. Gender and ethnic differences in incidence and survival of lymphoid neoplasm subtypes in an Asian population: secular trends of a population-based cancer registry from 1998 to 2012. Int J Cancer. 2015;137(11):2674-87.

8. Isobe Y, Tomomatsu J, Tsukune Y, Tsukada N, Sasaki M, Sugimoto K, et al. Diagnostic problems among chronic lymphocytic leukemia and other indolent B-cell leukemias in a Japanese population. Intern Med. 2012;51(15):1977-81.

9. Sun C, Tian X, Lee YS, Gunti S, Lipsky A, Herman SE, et al. Partial reconstitution of humoral immunity and fewer infections in patients with chronic lymphocytic leukemia treated with ibrutinib. Blood. 2015;126(19):2213-9.

10. Byrd JC, Brown JR, O’Brien S, Barrientos JC, Kay NE, Reddy $\mathrm{NM}$, et al. Ibrutinib versus ofatumumab in previously treated chronic lymphoid leukemia. N Engl J Med. 2014;371(3):213-23.

11. Ministry of Finance. Interest rate. Tokyo: 2015. http://www.mof. go.jp/english/jgbs/reference/interest_rate/index.htm. Accessed 1 Dec 2015.

12. Ministry of Health, Labor and Welfare. Patient survey (KanjaChosa). Tokyo: 2009. http://www.mhlw.go.jp/toukei/saikin/hw/ kanja/11/index.html. Accessed 1 Nov 2015.

13. Statistics Japan. Current population estimates. Tokyo: 2013. http://www.stat.go.jp/english/data/jinsui/2013np/index.htm. Accessed 1 Nov 2015.

14. Santos FP, O'Brien S. Small lymphocytic lymphoma and chronic lymphocytic leukemia: are they the same disease? Cancer J. 2012;18(5):396-403.

15. Ministry of Health, Labor and Welfare. Master of medical intervention (Iryo shinryou koui master). Tokyo: 2016. http:// www.iryohoken.go.jp/shinryohoshu/downloadMenu/. Accessed 25 May 2016.

16. Ministry of Health, Labor and Welfare. Master of pharmaceutical products (Iyakuhin master). Tokyo: 2016. http://www.iryohoken. go.jp/shinryohoshu/downloadMenu/. Accessed 25 May 2016.

17. Japanese Society of Hematology. Treatment guideline for hematopoietic tumor, therapy evaluation. http://www.jshem.or.jp/ gui-hemali/1_5.html.

18. Chang JE, Kahl BS. Bendamustine for treatment of chronic lymphocytic leukemia. Expert Opin Pharmacother. 2012;13(10):1495-505.

19. Leblond V. Use of bendamustine in chronic lymphocytic leukemia patients with co-morbidities. Eur Oncol Haematol. 2012;8(1):52-7.
20. Kotiah S. Chronic lymphocytic leukemia treatment protocols. New York: Medscape. http://emedicine.medscape.com/article/ 2005390-overview. Accessed 23 May 2016.

21. Wang K, Li P, Chen L, Kato K, Kobayashi M, Yamauchi K, et al. Impact of the Japanese diagnosis procedure combination-based payment system in Japan. J Med Syst. 2010;34(1):95-100.

22. Ministry of Health, Labor and Welfare. Point table of DPC. Tokyo. http://www.mhlw.go.jp/stf/seisakunitsuite/bunya/ 0000039920.html. Accessed 25 May 2016.

23. Japan Blood Products Association. Kensensho (infections). Tokyo. http://www.ketsukyo.or.jp/disease/infection/infection_02. html. Accessed 24 May 2016.

24. Fischer K, Cramer P, Busch R, Stilgenbauer S, Bahlo J, Schweighofer $\mathrm{CD}$, et al. Bendamustine combined with rituximab in patients with relapsed and/or refractory chronic lymphocytic leukemia: a multicenter phase II trial of the German Chronic Lymphocytic Leukemia Study Group. J Clin Oncol. 2011;29:3559-66.

25. Robak T, Dmoszynska A, Solal-Celigny $\mathrm{P}$, Warzocha $\mathrm{K}$, Loscertales J, Catalano J, et al. Rituximab plus fludarabine and cyclophosphamide prolongs progression-free survival compared with fludarabine and cyclophosphamide alone in previously treated chronic lymphocytic leukemia. J Clin Oncol. 2010;28(10):1756-65.

26. Blankart CR, Koch T, Linder R, Verheyen F, Schreyögg J, Stargardt $\mathrm{T}$, et al. Cost of illness and economic burden of chronic lymphocytic leukemia. Orphanet J Rare Dis. 2013;8:32.

27. Statistics Japan. Labour force survey. Tokyo: 2016. http://www. stat.go.jp/english/data/roudou/lngindex.htm. Accessed 15 Nov 2016.

28. Reis A, Ihle P, Paulus U, Ferber LV, Diehl V, Walshe R, et al. Cost of illness of malignant lymphoma in Germany. Eur J Cancer Care. 2006;15:379-85.

29. Tiessen J, Kambara H, Sakai T, Kato K, Yamauchi K, McMillan $\mathrm{C}$, et al. What causes international variations in length of stay: a comparative analysis for two inpatient conditions in Japanese and Canadian hospitals. Health Serv Manag Res. 2013;26(2-3):86-94.

30. Shanafelt TD, Borah BJ, Finnes HD, Chaffee KG, Ding W, Leis JF, et al. Impact of ibrutinib and idelalisib on the pharmaceutical cost of treating chronic lymphocytic leukemia at the individual and societal levels. J Oncol Pract. 2015;11(3):252-8.

31. Jang MA, Yoo EH, Kim K, Kim WS, Jung CW, Kim SH, et al. Chronic lymphocytic leukemia in Korean patients: frequent atypical immunophenotype and relatively aggressive clinical behavior. Int J Hematol. 2013;97(3):403-8.

32. Wu SJ, Chiang CJ, Lin CT, Tien HF, Lai MS. Improving but inferior survival in patients with chronic lymphocytic leukemia in Taiwan: a population-based study, 1990-2004. PLoS ONE. 2013;8(4):e62930.

33. Laugesen M, Glied S. Higher fees paid to US physicians drive higher spending for physician services compared to other countries. Health Aff. 2011;30(9):1647-56.

34. Danzon PM, Chao L-W. Cross-national price differences for pharmaceuticals: how large, and why? J Health Econ. 2000;19(2):159-95.

35. Mahon F, Réa D, Guilhot J, Guilhot F, Huguet F, Nicolini F, et al. Discontinuation of Imatinib in patients with chronic myeloid leukemia who have maintained complete molecular remission for at least 2 years: the prospective, multicenter Stop Imatinib (STIM) trial. Lancet Oncol. 2010;11(11):1029-35. 